\title{
Implementation of Traffic Information Zone in Czech Republic
}

\author{
Jakub Kraus \\ Department of Air Transport, \\ Department of Air Transport, Faculty of Transportation Sciences, Czech Technical University \\ Horská 3, Praha 2, 128 03, Czech Republic \\ e-mail: kraus@fd.cvut.cz
}

\begin{abstract}
This article focuses on the use of airspace, defined as traffic information zone for small aerodromes in the Czech Republic. This airspace should be around uncontrolled aerodromes introducing IFR operation to replace aerodrome traffic zone and to ensure the safe operation of aircraft flying by instruments.
\end{abstract}

Keywords - Small Aerodromes, VFR, IFR traffic, AFIS, TIZ, Traffic Information Zone, EGNOS

\section{INTRODUCTION}

Improving the quality of anything is a good input for economic growth. That is true of course also for aviation, which is constantly evolving industry. Despite the increasing quality of the techniques, however, it is not expected a rapid change in the volume of air traffic. Commercial air transport market is saturated and the current carriers can basically only fighting over passengers. Change in this case can come in rapidly developing countries such as India or China. In Europe, growth prospects are very limited and the growth is estimated to around $3 \%$ per year.

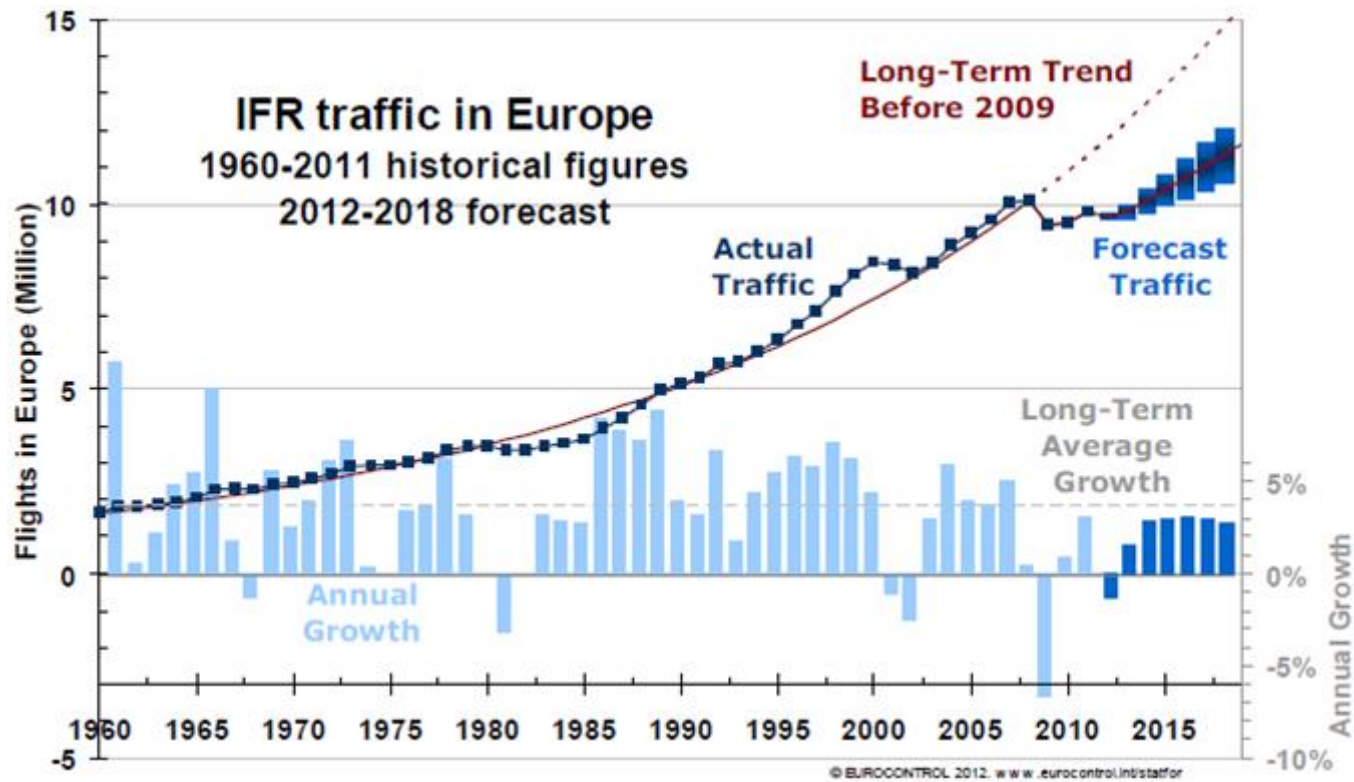

Figure 1. Eurocontrol IFR traffic forecast [14]
Therefore it would be appropriate to insert into the European air transport some momentum that would allow faster growth. The challenge, however, is to determine the correct part of aviation that still has enough options. This area could be general aviation with a clearer focus on larger GA aircrafts that have the avionics for IFR flying but they are struggling with a small number of IFR airports.

\section{ARGUMENTS FOR INCREASING THE NUMBER OF IFR AERODROMES}

This finding of a small number of IFR airports is based on a study carried out by Eurocontrol, which interviewed IFR pilots who are aware of the SBAS. This questionnaire was completed by 254 pilots, which is not sufficient for clear identification of possible causes of SBAS little usage in Europe, but some conclusions can be drawn from the results.

One of them is the fact that almost $48 \%$ of the people surveyed fly in machines with SBAS capable avionics, although not all of them could be used for APV approach.

However, the most important outcome is identifying of the two main barriers to the use of procedures requiring SBAS. The first one is the cost (either for certification, avionics acquisition, installation) and the second one is an insufficient number of publicated procedures. They were identified as a major cause in $30 \%$ responces. 


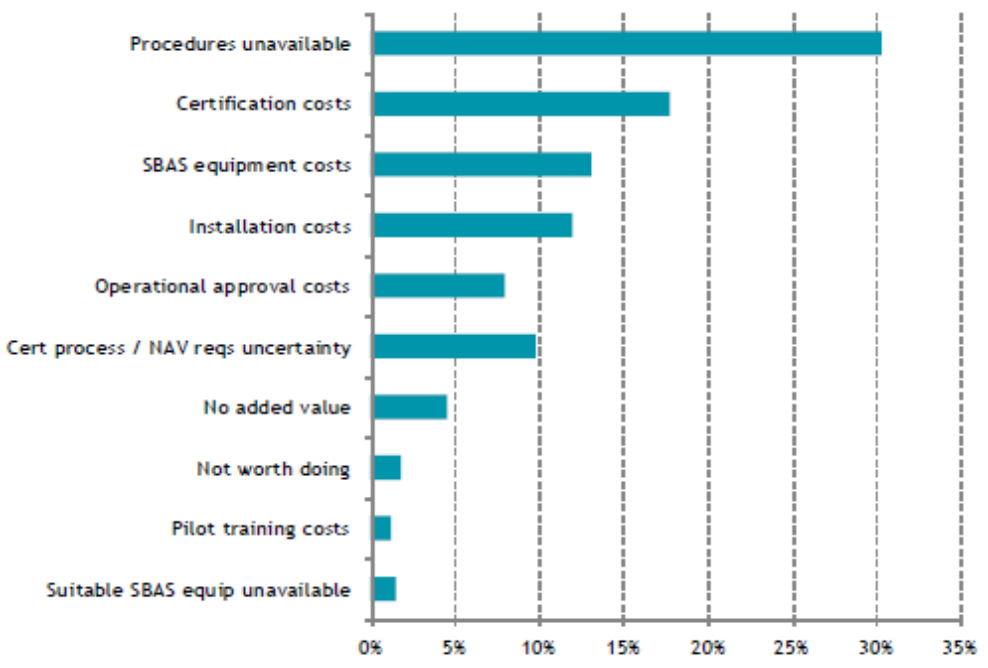

information is provided by an ATS unit. TIZ basically provides same function for uncontrolled aerodromes as the CTR for controlled ones.

\section{A. The Norwegian example}

Among the European countries using TIZ is Norway. This airspace was introduced in order to allow flights at uncontrolled aerodromes in meteorological conditions which do not meet the VMC minima. In traffic information zone is provided AFIS and mandatory two-way radio communication ensures that AFIS officer may transmit information to all aircraft about all traffic located in TIZ.

Pilots are still responsible for maintaining separation, which may be in IMC quite a challenge. Therefore AFIS tend to have available output from surveillance systems for the accurate location information of other traffic. In some cases the number

Figure 2. Obstacles to the use of SBAS / EGNOS [15]

Removal of the main obstacles, lack of procedures, is the best option for extending the use of EGNOS in Europe. Currently, approaches utilizing satellite augmentation are implemented only at 84 airports in Europe, from which only 46 are RNP APCH down to LPV.

In all 6500 airports in Europe are 84 procedures noticeably small number. It should be noted that RNP APCH down to the LPV is ranked as instrument approach and therefore it is possible to implement it only at IFR airports. These, however, are only a fraction of the total number, which is why some states are trying to allow IFR traffic at VFR aerodromes. Examples might be Germany, the United Kingdom, and Norway, Sweden and Denmark.

If we focus only on the Czech Republic, then from a total of 92 aerodromes are only 8 instrument ones that is only $7 \%$. To encourage aviation, it is therefore necessary choose other airports that allow instrument approaches.

\section{TIZ}

The main obstacle to the introduction of IFR operations at the VFR aerodrome is maintaining the level of safety: to ensure separation between aircraft and to enable landing at aerodromes, which do not meet the conditions for IFR operations.

The airspace around uncontrolled aerodromes in Europe is generally classified as ATZ with dimensions of $3 \mathrm{NM}$ radius and height of $4000 \mathrm{ft}$ AMSL. This size is insufficient for IFR operations and for this reason it is necessary to either enlarge the size of ATZ or introduce other airspace for VFR aerodromes with IFR traffic.

This option may be an area called the Traffic Information Zone (TIZ), which is mentioned in the Eurocontrol AFIS manual. The definition of TIZ is: An uncontrolled airspace of defined dimensions extending upwards from the surface of the earth to a specified upper limit within which two-way communications is required for all aircraft and flight limited.

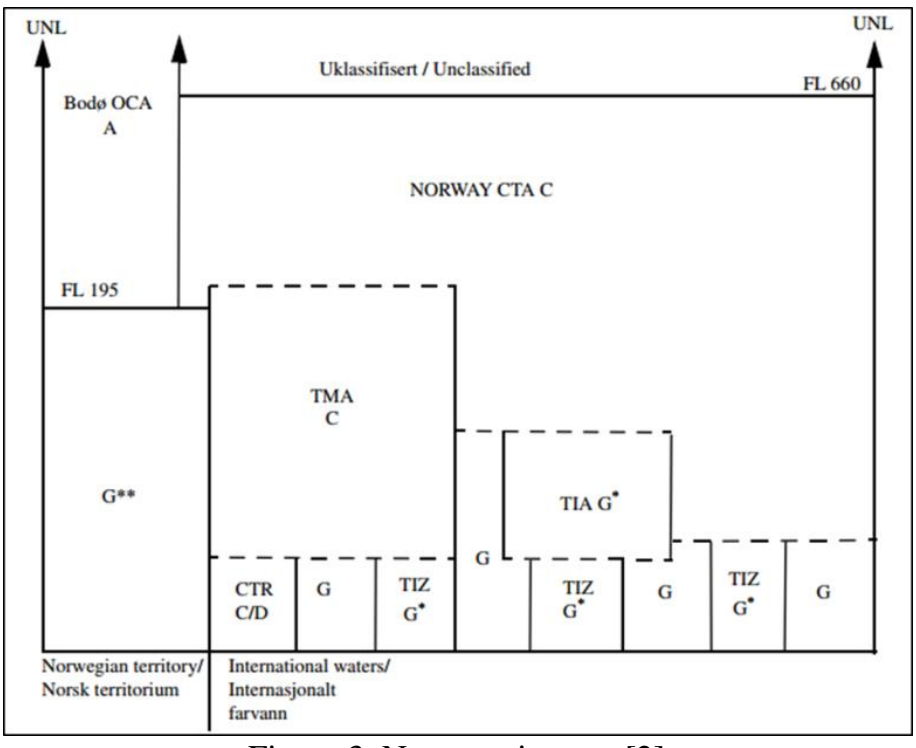

Figure 3. Norway airspace [2]

Figure 3 shows the location of the various TIZ areas, classified airspace class $G^{*}$. This means ICAO Class $G$ with mandatory two-way radio communications.

TIZ important feature is that the regulations do not strictly defined its dimensions and therefore it is always possible to establish the best airspace for each aerodrome, which it is not possible when using ATZ. 

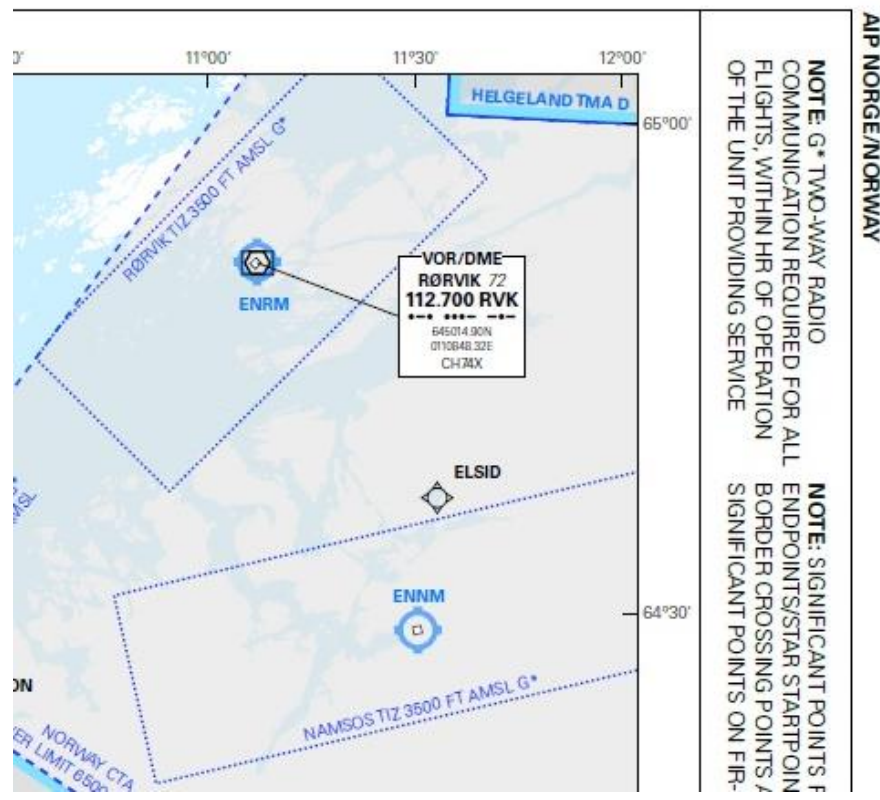

Figure 4. Part of Norway area map showing TIZs [2]

\section{IV.THE USE OF TIZ IN THE CZECH REPUBLIC}

According to the above information, it is clear that TIZ should be implemented in the Czech Republic at selected uncontrolled aerodromes. However, to simplify the implementation this airspace could have defined dimensions, ensuring smooth operation of the IFR.
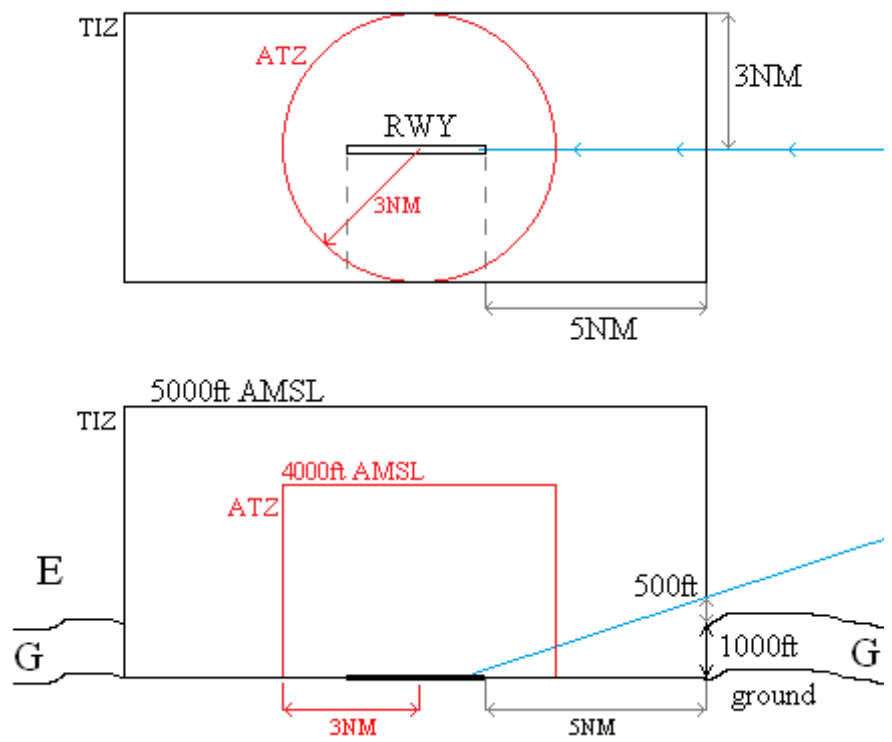

Figure 5. Proposed TIZ for Czech Republic

Figure 5 shows a comparison of proposed TIZ and present ATZ. The biggest obstacle of ATZ is the horizontal size of this airspace, which does not allow the creation of a direct approach route that would not missed class $G$ airspace. In Czech Republic is this airspace defined as uncontrolled where IFR flights are not allowed. TIZ would have to be classified with modified class $\mathrm{G}$ (as has Norway), or there is the possibility to use class $\mathrm{F}$. The $\mathrm{F}$ class is defined in $\mathrm{L}$ regulations, but it is unused in the airspace of the Czech Republic.

In the dimensions of TIZ, 5 NM from the runway threshold, $3 \mathrm{NM}$ from the runway centre line and height of $5000 \mathrm{ft}$ AMSL could be radar vectored aircraft by the ACC controller with subsequent use of RNP APCH down to LPV. Spacing would be ensured procedurally that the controller will give approach clearance only to one aircraft at one time. Another aircrafts would have to wait until ATC get the information about flight cancelation. With the coordination of ATC and AFIS would be also protected the departing aircrafts.

As mentioned, although the pilot is still responsible for the spacing from other traffic, by using a procedural control and mandatory two-way radio communication possibility of conflict would be greatly reduced in TIZ. In VMC is the traffic seen and in IMC cannot be present VFR flights, because of IMC, and IFR flights because of procedural control.

\section{A. VFR aerodromes for IFR traffic}

This airspace could be used for larger VFR aerodromes in the Czech Republic, such as České Budějovice, Hradec Králové, and also Benešov.

TABLE I. CZECH AERODROMES CAPABLE FOR TIZ IMPLEMENTATION

\begin{tabular}{|l|c|l|}
\hline Aerodrome & ICAO code & Surface \\
\hline České Budějovice & LKCS & Asphalt/concrete \\
\hline Hořovice & LKHV & Asphalt/concrete \\
\hline Hosín & LKHS & Asphalt/concrete \\
\hline Hradec Králové & LKHK & Asphalt/concrete \\
\hline Jindřichův Hradec & LKJH & Asphalt/concrete \\
\hline Křŕženec & LKKC & Asphalt/concrete \\
\hline Mnichovo Hradiště & LKMH & Asphalt/concrete \\
\hline Otrokovice & LKOT & Asphalt/concrete \\
\hline Panenský Týnec & LKPC & Asphalt/concrete \\
\hline Plzeň - Líně & LKLN & Asphalt/concrete \\
\hline Přerov & LKPO & Asphalt/concrete \\
\hline Příbram & LKPM & Asphalt/concrete \\
\hline Vysoké Mýto & LKVM & Asphalt/concrete \\
\hline Benešov & LKBE & Grass \\
\hline
\end{tabular}

\section{B. Needed regulation changes}

The introduction of TIZ into Czech legislation would not be very difficult step and will significantly affect mainly the regulations L 2, L 11, L 7030 and AIP. The actual implementation would, however, require safety analysis to confirm that the introduction of TIZ is not more dangerous than the status quo. The safety analysis must be based on the risks caused by processes during approach and landing. Here arises a suitable comparison between the precision approach to airport and proposed approach to an uncontrolled aerodrome. 


\section{CONCLUSION}

Traffic Information Zone is a simple tool which can improve the quality of air traffic in the Czech Republic. Thanks considered changes in the ways in providing AFIS, which must be certified, it would be possible to ensure safe operation of the instrument flights at aerodromes that do not have an air traffic control.

Although it is clear that the introduction of IFR operations at most of the aerodromes in the Czech Republic would increase the possibilities for air traffic, to quantify the contribution of this step in relation to the expended effort is difficult. Thanks to the experience and activities of other European countries, however, this seems like the right direction for development. From an economic point of view, the state funds given in the transformation of airspace change, thus in transport infrastructure, will return several times in economic growth.

From the safety perspective would TIZ request an operational and safety analysis to identify the limits of characteristics which could be used for TIZ implementation and other subsequent changes.

\section{ACKNOWLEDGEMENTS}

This paper was supported by the Grant Agency of the Czech Technical University in Prague, grant No. SGS13/090/OHK2/1T/16.

\section{[1] AIP}

$$
\begin{array}{ll} 
& \text { REFERENCES } \\
\text { ČR } & \text { [online]. }
\end{array}
$$

Available at $<$ http://lis.rlp.cz/ais_data/www_main_control/frm_cz_aip.ht $\mathrm{m}>$

[2] AIP Norway [online]. Available at <https://www.ippc.no/norway_aip/current/main_no.html>

[3] AIP Germany [online]. Available at $<$ http://www.ead.eurocontrol.int/publicuser/public/pu/login. jsp>
[4] Eurocontrol AFIS manual [online]. Eurocontrol. Available at <http://www.skybrary.aero/bookshelf/books/1446.pdf>

[5] L standards - ICAO Annexes [online]. Available at <http://lis.rlp.cz/predpisy/predpisy/index.htm>

[6] Navigation strategy for ECAC. [online]. Eurocontrol, 1999. Available at:

<http://www.ecacnav.com/downloads/Navigation\%20Strate gy.pdf>

[7] GNSS v Evropě. Czech Space Portal. [online] Ministerstvo dopravy ČR, 2011. [Cit. 10. 12 2012.] Available at: $<$ http://www.czechspaceportal.cz/3-sekce/gnsssystemy/gnss-v-evrope/>

[8] ICAO Doc 9849 Global Navigation Satellite System Manual. [PDF] Montreal : ICAO, 2005. Available at: <http://www.icao.int/Meetings/PBNSymposium/Documents/9849_cons_en[1].pdf>

[9] L 8168 Letecký předpis. [online]. Available at: <http://lis.rlp.cz/predpisy/predpisy/index.htm>

[10] Holzer, Mark. GPS LPV Approach Establishment. [online]. FAA, 2010. Available at: <http://www.faa.gov/airports/great_lakes/about_airports/bis ado/bis_ado_web/media/handouts/GPS2010MJH.pdf>

[11] Duka, Tomáš. Implementace PBN v ČR. [online] Praha : ŘLP a.s., s.p., 2011. Available at: $<$ lis.rlp.cz/cz/prezentaceGA/Nav_PBN.pps>

[12] Koncepce rozvoje navigačního prostředí $\mathrm{v}$ podmínkách ČR. [PDF] Jeneč : ̌̌LP a.s. s.p., 2012.

[13] Guidance Material for The Implementation of RNP APCH Operations. [online]. EUROCONTROL, 2012. Available at:

<http://www.paris.icao.int/documents_open_meetings/show _file.php?id=1530>

[14] EUROCONTROL Medium-Term Forecast of Flights (2012-2018). [online]. EUROCONTROL, 2011. Available at: <http://www.eurocontrol.int/documents/eurocontrolmedium-term-forecast-flights-2012-2018>

[15] RESULTS OF A SURVEY OF IFR GA IN EUROPE ON SBAS. [online] EUROCONTROL, 2013. Available at: <http://www.paris.icao.int/documents_open_meetings/show _file.php?id=1668> 